\title{
KELIMPAHAN KUMBANG KUBAH PREDATOR PADA BERBAGAI GENOTIPE TANAMAN SORGUM (Sorghum Bicolor [L.] Moench) YANG DITANAM SECARA MONOKULTUR DAN TUMPANGSARI DENGAN TANAMAN UBIKAYU
}

\section{THE ABUNDANCE OF PREDATORY COCCINELLID BEETLES ON VARIOUS GENOTYPES OF SORGUM (Sorghum Bicolor [L.] Moench) THAT CULTIVATED MONOCULTURE AND INTERCROPPING WITH CASSAVA PLANTS}

\author{
R. M. Ulin Nadhif ${ }^{1}$, F. X. Susilo ${ }^{2}$, M. Syamsoel Hadi ${ }^{3}$ dan Purnomo ${ }^{2}$ \\ ${ }^{1}$ Jurusan Agroteknologi Fakultas Pertanian Universitas Lampung \\ ${ }^{2}$ Jurusan Proteksi Tanaman Fakultas Pertanian Universitas Lampung \\ ${ }^{3}$ Jurusan Agronomi dan Hortikultura Fakultas Pertanian Universitas Lampung \\ *Email: romanadhif17@gmail.com \\ *Corresponding Author, Diterima: 4 Mei 2021, Direvisi: 24 Mei 2021, Disetujui: 30 Juli 2021
}

\begin{abstract}
The study aims to determine the effect of sorghum plant genotypes and cropping patterns on the abundance of predatory coccinellid beetles in sorghum plants. The study was conducted in the Integrated Field of the Faculty of Agriculture, University of Lampung from March to August 2017. The treatments were arranged in a split plot design with 3 replications. The main plot was the cropping pattern and subplot was sorghum genotypes (15 genotypes). Data were analyzed using analysis of variance followed by least significant difference test at 0,05 significance level. Sorghum genotype significantly affected the predatory coccinellid beetle abundance with the Talaga Bodas genotype having the highest predatory coccinellid beetle abundance and Numbu genotype had the lowest abundance. Cropping patterns do not affect the abundance of predatory coccinellid beetles. The interaction between sorghum genotypes and cropping patterns occurred at the fifth observation (7 WAP), in which the predatory dome beetles abundance was found in GH-6 when planted as monoculture.
\end{abstract}

Keywords: Cropping patterns, genotype, predator coccinellid beetles, sorghum.

\begin{abstract}
ABSTRAK
Penelitian bertujuan untuk mengetahui pengaruh genotipe tanaman sorgum dan pengaruh pola tanam terhadap kelimpahan kumbang kubah predator pada tanaman sorgum. Penelitian dilakukan di Lapangan Terpadu Fakultas Pertanian Universitas Lampung dari bulan Maret sampai Agustus 2017. Perlakuan disusun dalam rancangan petak terbagi (split plot design) dengan 3 ulangan (blok). Petak utama adalah pola tanam (monokultur vs tumpangsari) dan anak petak adalah genotipe sorgum (15 genotipe). Data dianalisis ragam (taraf nyata 0,01 ) dilanjutkan dengan uji beda nyata terkecil (BNT) pada taraf nyata 0,05 . Genotipe sorgum berpengaruh nyata terhadap kelimpahan kumbang kubah predator coccinellidae (genotipe Talaga Bodas memiliki kelimpahan kumbang kubah tertinggi dan Numbu dengan kelimpahan kumbang kubah terendah). Pola tanam tidak bepengaruh
\end{abstract}


terhadap kelimpahan kumbang kubah predator. Interaksi antara genotipe sorgum dan pola tanam terjadi pada pengamatan ke lima (7 MST), pada pengamatan ini kelimpahan kumbang kubah predator ditemukan pada GH6 monokultur.

Kata kunci : Genotipe, kumbang kubah predator, pola tanam, sorgum.

\section{PENDAHULUAN}

Tanaman sorgum dapat ditanam di daerah beriklim tropis, seperti Indonesia. Sorgum memiliki potensi dikembangkan menjadi salah satu alternatif memenuhi kebutuhan bahan pangan, pakan serta industri daerah tropis (House, 1995). Long (1994) dalam Hasanah (2010) telah menyatakan bahwa kutu daun merupakan hama pada tanaman sorgum. Serangan hama kutu daun menyebabkan sorgum kerdil dan menyebabkan kematian sebelum waktunya (Akhtar dan Delahaut, 2004 dalam Hasanah, 2010).

Musuh alami kutu daun adalah kumbang kubah Coccinellidae. Menurut Hasanah (2010), musuh alami kutu daun yang banyak ditemukan dalam pertanaman adalah predatornya yaitu kumbang kubah Coccinellidae. Pengendalian secara alami dengan kumbang kubah predator diharapkan dapat menekan populasi kutu daun pada tanaman sorgum.

\section{BAHAN DAN METODE}

Tempat dan waktu. Penelitian dilakukan di Laboratorium Lapangan Terpadu Universitas Lampung, Kota Bandar Lampung, Provinsi Lampung. Penelitian ini dilaksanakan dalam waktu kurang lebih 3 bulan, dari bulan April hingga bulan Juni tahun 2017.

Alat dan Bahan. Alat yang digunakan di dalam penelitian kali ini antara lain cangkul, bambu, paku, palu, papan triplek ukuran 30x40 cm dan 60x $100 \mathrm{~cm}$, alat tulis (pen/pensil, spidol, penghapus/tip-x), borang pengamatan, papan ujian, botol, kuas lukis, kamera, dan kertas label. Bahan yang digunakan adalah benih tanaman sorgum PI-WHP(G1), Talaga Bodas (G2), GH-3 (G3), GH-4 (G4), GH-5 (G5), GH-6 (G6), GH-7 (G7), GH-13 (G8), Numbu (G9), P/F 5-193C (10), Super-2 (G11), Super-1 (G12), Mandau(G13), Samurai-1 (G14), UPCA (G15) dan bibit ubikayu dengan varietas Kasetsart (UJ5), dan alkohol 70\%.

Percobaan disusun menggunakan Rancangan Petak Terbagi (Split Plot Design) terdiri dari petak utama adalah pola tanam monokultur dan tumpangsari sedangkan anak petak adalah 15 genotipe sorgum. Percobaan dilakukan dengan 3 kali ulangan. Total satuan percobaan adalah $(2 \times 15) \times 3=90$ satuan percobaan.

Penanaman. Penanaman dilakukan dengan cara tugal pada lubang tanam sedalam $3-5 \mathrm{~cm}$. Setiap lubang tanam diisi dengan 5 benih sorgum. Jarak tanam tanaman sorgum $20 \times 80 \mathrm{~cm}$ dan ubikayu dengan panjang $25-30 \mathrm{~cm}$. Jarak tanam ubikayu yang digunakan adalah $60 \times 80 \mathrm{~cm}$.

Penyulaman. Tanaman yang dijadikan sulaman dipilih dari tanaman yang sudah ditanam pada waktu yang bersamaan dengan tanaman utama. Penyulaman dilakukan paling lambat yaitu 2 minggu setelah penanaman. Tanaman yang dijadikan tanaman sulaman sama genotipenya dengan tanaman yang akan disulam.

Penjarangan. Penjarangan dilakukan pada saat 
2 minggu setelah waktu tanam. Tanaman yang disisakan dengan jumlah maksimal 3 batang tanaman per lubang tanam. Penjarangan tidak dilakukan apabila pada satu lubang tanam hanya terdapat 3 atau kurang tanaman yang tumbuh.

Pemeliharaan. Pemeliharaan meliputi penyiraman dan penyiangan gulma. Penyiraman dilakukan untuk memberikan ketersediaan air di dalam tanah untuk membantu proses fotosintesis pada tanaman. Penyiraman dilakukan ketika tidak adanya hujan dan dilakukan pada bulan pertama. Penyiangan gulma dilakukan dengan cara manual yaitu dengan mengoret gulma yang ada pada petak percobaan.

Pengamatan. Variabel yang diamati ialah kelimpahan kumbang kubah predator (Coleoptera: Coccinellidae). Pengamatan pertama dilakukan terhadap semua rumpun tanaman sorgum yang ada pada setiap petak percobaan. Proses pengamatan yang dilakukan adalah menghitung jumlah rumpun tanaman yang ada di setiap baris tanaman. Kelimpahan kumbang kubah predator merupakan banyaknya kumbang kubah predator pada baris tanaman sorgum.

Analisis Data. Homogenitas ragam diuji dengan uji Bartlett sedangkan aditivitas data diuji dengan uji Tukey. Kedua uji tersebut dilakukan pada taraf $5 \%$. Setelah asumsi terpenuhi, data kelimpahan kumbang kubah predator (ekor/rumpun) dilakukan analisis ragam (ANARA) pada taraf 5\% dan uji perbedaan nilai tengah diuji dengan uji beda nyata terkecil (BNT) pada taraf 5\%.

\section{HASIL DAN PEMBAHASAN}

Hasil. Hasil penelitian yang telah dilakukan menunjukkan bahwa pola tanam monokultur maupun tumpangsari tidak berpengaruh nyata terhadap kelimpahan kumbang kubah predator pada tanaman sorgum. Hasil penelitian menunjukkan bahwa genotipe sorgum berpengaruh nyata terhadap kelimpahan kumbang kubah predator (Tabel 1). Pengaruh nyata genotipe sorgum terhadap kelimpahan kumbang kubah predator terdapat pada pengamatan ke lima (7MST). Pengamatan ke lima(7 MST)juga menunjukkan bahwa interaksi pola tanam dengan genotipe sorgum berpengaruh nyata terhadap kelimpahan kumbah kubah predator (Tabel 1).

Hasil analisis menunjukkan bahwa pada genotipe sorgum Talaga Bodas kelimpahan kumbang kubah predator tinggi. Hal tersebut teramati pada

Tabel 1. Analisis ragam kelimpahan kumbang kubah predator pada 15 genotipe sorgum pada pengamatan ke lima (7 MST).

\begin{tabular}{lccccccc}
\hline \multicolumn{1}{c}{ SK } & $\mathrm{dk}$ & $\mathrm{JK}$ & KT & F-hitung & F-tabel 5\% & F-tabel 1\% \\
\hline Blok & 2 & 32,6 & 16,3 & 4,1 & tn & 19,0 & 99,0 \\
Pola Tanam & 1 & 13,6 & 13,6 & 3,4 & tn & 18,5 & 98,5 \\
Galat (PU) & 2 & 10,8 & 5,4 & & & & \\
Genotipe & 14 & 111,5 & 8,0 & 2,0 & $*$ & 1,9 & 2,4 \\
PT x G & 14 & 104,6 & 7,5 & 1,9 & $*$ & 1,9 & 2,4 \\
Galat (AP) & 56 & 222,6 & 4,0 & & & & \\
Nonaditivitas & 1 & 3,7 & 3,7 & 0,9 & th & 4,0 & 7,1 \\
Sisa & 55 & 218,9 & 4,0 & & & & \\
\hline Total & 89 & 495,7 & & & & & \\
\hline
\end{tabular}


pengamatan ke empat (6 MST), ke lima(7 MST), dan ke enam ( 8 MST) pada genotipe ini. Hasil analisis menunjukkan bahwa genotipe Numbu memiliki kelimpahan kumbang yang rendah. Hal tersebut dilihat dari konsistensi kelimpahan kumbang kubah yang tergolong rendah dan memiliki kelimpahan kumbang predator yang terendah pada pengamatan pertama (3 MST) (Gambar 1).

Pembahasan. Hasil penelitian secara umum menunjukkan bahwa kelimpahan kumbang kubah predator bervariasi pada tanaman sorgum. Pada pengamatan ke lima (7 MST) kelimpahan kumbang tertinggi pada genotipe GH-6 yang ditumpangsarikan. Pada monokultur genotipe GH-6 kelimpahan kumbang kubah predator rendah. Genotipe Numbu memiliki kelimpahan kumbang kubah predator yang juga rendah. Hal tersebut sesuai dengan deskripsi genotipe Numbu yang menyatakan bahwa genotipe Numbu memiliki sifat ketahanan yang baik terhadap hama kutu daun. Kelimpahan kumbang kubah predator yang rendah pada genotipe Numbu terkait dengan kelimpahan kutu daun yang rendah pada genotipe Numbu ini.

Kelimpahan kumbang kubah pada genotipe Talaga Bodas juga tinggi, dan mengindikasikan bahwa genotipe Talaga Bodas memiliki sifat ketahanan yang rendah terhadap hama kutu daun. Kelimpahan kumbang predator yang tinggi maupun rendah pada berbagai genotipe sorgum dimungkinkan adanya keterlibatan sinomon, suatu zat yang dikeluarkan tanaman yang bertujuan mendatangkan predator untuk menemukan mangsanya. Setiap genotipe sorgum memiliki kemampuan yang berbeda-beda dalam mengeluarkan sinomon.

Ada kemungkinan bahwa tanaman sorgum mengeluarkan sinomon pada saat hama kutu daun menyerang sebagai isyarat agar kumbang kubah predator datang untuk menemukan mangsanya itu. Nordlund dan Lewis (1976) dalam Price (1997) menyatakan bahwa sinomon menguntungkan secara adaptifbaik untuk tanaman maupun predator. Tanaman

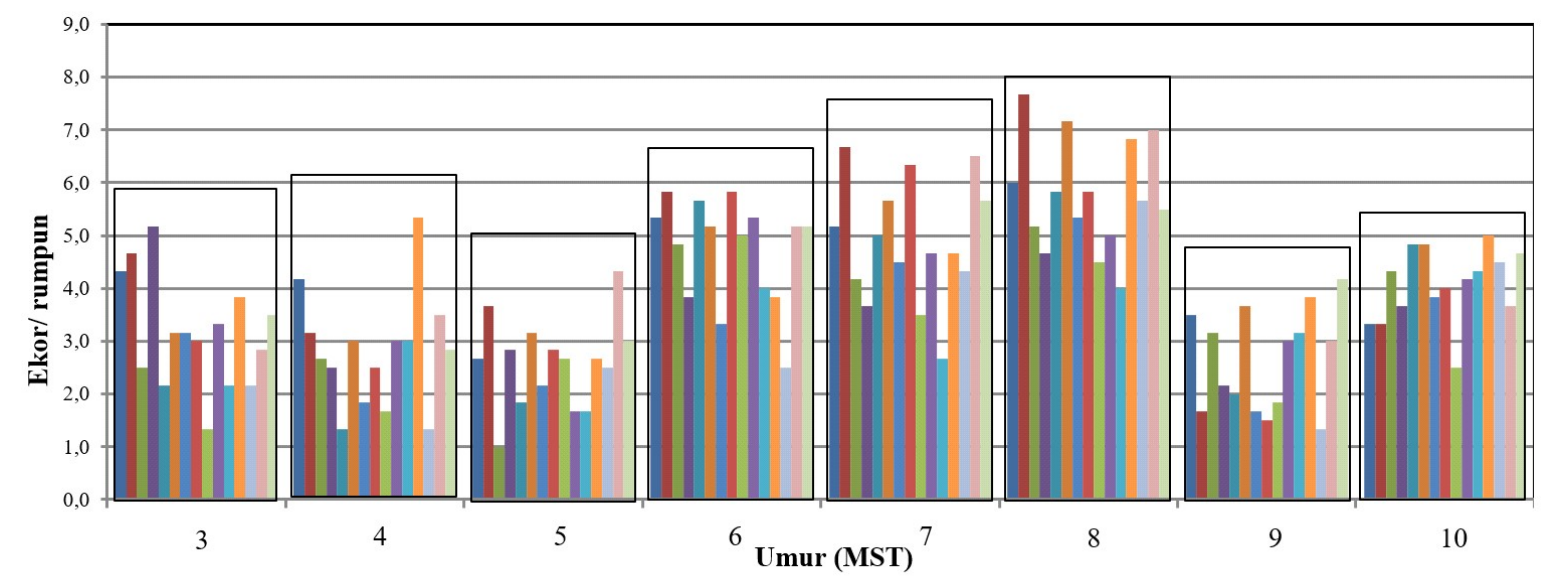

Gambar 1. Kelimpahan kumbang kubah pada berbagai umur 15 genotipe sorgum

Keterangan :^: P/I WHP,п: T. Bodas, ๘: GH-13, : Numbu, : P/F5-193C, $\leftleftarrows$ : Super 2, : Super 1, : Mandau, $\llbracket:$ Samurai1, $\leftleftarrows$ : UPCA. 
yang terserang hama dapat mengeluarkan isyarat kimia itu (sinomon) yang digunakan tanaman untuk mendatangkan predator guna menemukan mangsanya yang menyerang tanaman tersebut. Fenomena ini mirip dengan yang terjadi pada taanaman Brussels Sprout yang didatangi musuh alami (parasitoid) dariulat Pieris karena adanya sinomon.

\section{KESIMPULAN}

Dari penelitian ini dapat disimpulkan bahwa pola tanam tanaman sorgum tidak berpengaruh nyata terhadap kelimpahan kumbang kubah predator Coccinellidae, tetapi genotipe tanaman sorgum berpengaruh nyata terhadap kelimpahan kumbang kubah predator coccinellidae. Genotipe sorgum yang memiliki kelimpahan kumbang kubah tertinggi adalah genotipe Talaga Bodas, sedangkan genotipe dengan kelimpahan terendah adalah genotipe Numbu.

\section{DAFTAR PUSTAKA}

Hasanah, H. A. 2010. Perkembangan Populasi Rhopalosiphum maidis Fitch (Hemiptera: Aphididae) dan MusuhAlaminya Pada Tanaman Jagung Manis (Zea mays Saccharata Sturt). Skripsi. Departemen Proteksi Tanaman Institut Pertanian Bogor.Bogor.

House, L. R. 1995. A Guide to Sorghum breeding. International Crops Research Institute for Semi Arid Tropics. Andhra Pradesh. India. $206 \mathrm{p}$.

Mattiacci, L., Dicke, M., and Posthumus A. M. 1994. Induction of Parasitoid Attracting Synomone In Brussels Sprouts Plants By Feeding of Pieris Brassicae Larvae: Role Of Mechanical Damage And Herbivore Elicitor. Journal of Chemical Ecology 20 (9) : 2229-2247 Wageningen. The Netherlands.

Price, P. W. 1997. Insect Ecology. Northem Arizona University. United States of America. 888 p. 